\title{
Provision of health advice for UK medical students planning to travel overseas for their elective study period: questionnaire survey
}

\author{
Peter J Moss, Nick J Beeching
}

An external elective period is included in the curriculum of most medical schools in the United Kingdom. Of this year's applicants for elective grants at one school, $97 \%$ planned to go abroad; $69 \%$ of applicants chose developing countries, the most popular destination being southern Africa. Attention has been drawn to the potential health risks facing elective students (J H Cossar et al, fifth international conference on travel medicine, 1995 (abstract 201)) and also to the risk of HIV infection for health workers in developing countries. ${ }^{1}$ We conducted a survey to determine how health advice for elective students who plan to travel abroad is provided.

\section{Methods and results}

We sent a questionnaire to the 26 medical schools in the United Kingdom after making a telephone call to determine the most appropriate addressee. A telephone reminder was made to those who had not responded after four weeks. Further detail about the questionnaire is on the $B M J$ s s website.

Twenty two replies $(85 \%)$ were received (table). Of the medical schools from which no response had been received, two stated at the reminder call that the addressee was on leave and two that the form would be returned soon.

Most medical schools (20) that replied provided some form of travel health advice, usually in the form of a group lecture or seminar. Some distributed written guidance: this ranged from a single paragraph about health in a document covering various elective issues, to a comprehensive 12 page guide to travel and occupational health. Few schools (7) made internal provision for immunisations, and many of those that did not make such provision also had no check on whether students had followed the advice given. Only 2 schools offered routine health screening to elective students on their return.

Almost all the respondents (21) said that students were given advice about HIV infection. In many cases, however, this was as part of the normal curriculum, and academic knowledge concerning HIV infection and AIDS in Britain does not necessarily correlate with an understanding of the personal risks involved in working in the developing world. Most schools had not considered how current guidelines for the management of occupational exposure to HIV could be applied to overseas elective students. ${ }^{2}$

\section{Comment}

The attitude of medical schools towards the occupational health of students going on overseas electives varies considerably. Some schools take a "hands off" attitude: "At the end of the day, they are adults, after all." Others are far more restrictive, refusing to sanction electives to countries where there are considered to be serious health risks. There should be more consistency in pre-elective preparation for medical students, with standardised written advice produced in collaboration with expert groups. Some schools may not have the facilities to provide individual advice and immunisations but could advise students where these could be obtained. Schools could also provide a checklist for each student, to be signed by the general practitioner or doctor at the travel centre, confirming that appropriate advice had been received and (in the case of immunisation) followed. Health screening after overseas electives is of limited value in preventing illness $^{3}$ but would provide useful feedback on the efficacy of measures taken before travel: a structured health questionnaire would be adequate in most cases.

The problem of occupational exposure to infection, particularly HIV, is more difficult. One solution, already adopted by at least two schools, is to discourage students strongly from going to areas with a high prevalence of HIV infection. Much of the developing world, however, now has a high prevalence, ${ }^{4}$ and students may therefore be denied a valuable experience. Post-exposure prophylaxis will not be available in many parts of the world, and the expense of providing drugs for students to take with

Responses of 22 medical schools who returned questionnaire

\begin{tabular}{|c|c|c|}
\hline Question & $\begin{array}{l}\text { No of respondents } \\
\text { answering yes }\end{array}$ & Comments \\
\hline $\begin{array}{l}\text { Is travel health information provided by medical school or } \\
\text { occupational health department? }\end{array}$ & 20 & $\begin{array}{l}\text { Written information provided by } 11 \text { schools } \\
\text { (7 of which sent copies with their returned questionnaires) }\end{array}$ \\
\hline $\begin{array}{l}\text { Are immunisations arranged by medical school or occupational health } \\
\text { department? }\end{array}$ & 7 & \\
\hline $\begin{array}{l}\text { Does medical school check whether advice and immunisations have } \\
\text { been received? }\end{array}$ & 10 & $\begin{array}{l}\text { No checks were done in } 1 \text { school that did not provide advice and in } \\
7 \text { that did not arrange immunisation }\end{array}$ \\
\hline Is a health check on return to Britain offered? & 2 & A further 3 schools provided health check on request \\
\hline Is information on occupational exposure to HIV given to students? & 20 & Often as part of normal curriculum \\
\hline $\begin{array}{l}\text { Is information on sexually transmitted diseases (including HIV } \\
\text { infection) given to students? }\end{array}$ & 20 & Often as part of normal curriculum \\
\hline $\begin{array}{l}\text { Is post-exposure prophylaxis available to students on overseas } \\
\text { electives? }\end{array}$ & 2 & $\begin{array}{l}\text { A further school said that it advised students about post-exposure } \\
\text { prophylaxis; } 2 \text { further schools said that they did if the student } \\
\text { was doing an "affiliated centre elective"; a further } 3 \text { said "yes, in } \\
\text { certain locations" }\end{array}$ \\
\hline
\end{tabular}

Editorial by

Wilkinson and p 158

Division of Tropical Medicine, Liverpoo School of Tropical Medicine, Liverpool L3 5QA

Peter J Moss, honorary clinical lecture

Nick J Beeching, senior lecturer

Correspondence to: Dr Beeching

NBeeching@aol.com

BMJ 1999;318:161-2

website

extra

Additional

information about the questionnaire appears on our website

www.bmj.com 
them is likely to be unacceptable. Some institutions have already started to think about the implications for their own students, but widespread consultation does not seem to have taken place. Future practice should be based on a policy decided nationally.

We thank the staff of the medical schools who took the time to complete our questionnaire, and our colleagues Charles Gilks, Fred Nye, Bertie Squire, and Sharon Welby for helpful discussion and comments on the article.

Contributors: Both authors conceived and designed the study and wrote the paper. PJM conducted the telephone enquiries and postal survey.
Funding: None.

Competing interests: None declared.

1 Gilks CF, Wilkinson D. Reducing the risk of nosocomial HIV infection in British health workers working overseas: the role of post-exposure prophylaxis. BMJ 1998;316:1158-60.

2 Expert Advisory Group on AIDS. Guidelines on post-exposure prophylaxis for health care workers occupationally exposed to HIV.London: Department of Health, 1997.

3 Ellis C. Post-tropical screening [letter]. BMJ 1993;307:1008

4 UNAIDS. Report on the global HIV/AIDS epidemic. Geneva: UNAIDS, World Health Organisation, 1998:63-4.

(Accepted 23 October 1998)
AIDS Prevention

Division, Child

Foundation of

India,

Visakhapatnam

530 008, Andhra

Pradesh, India

Kootikuppala Surya

Rao,

director

R D Pilli,

senior associate

A S Rao,

research associate

P S Chalam,

research associa

Correspondence to:

Dr K S Rao, Sri

Surya Clinic

Buildings,

Kancharapalem

Main Road,

Visakhapatnam

530 008, Andhr

Pradesh, India

BMJ 1999;318:162-3

\section{Sexual lifestyle of long distance lorry drivers in India: questionnaire survey}

\author{
Kootikuppala Surya Rao, R D Pilli, A S Rao, P S Chalam
}

India has one of the largest road networks in the world and an estimated 5 million long distance lorry drivers. These men are away from their families for long durations, and in the unhealthy environment along the highways they become easy prey for commercial sex workers. This environment has brought new dimensions to their lifestyle. A recent study of Thai long haul truck drivers found that $86 \%$ of the single men and $63 \%$ of the married men had had commercial sex. ${ }^{1}$ We studied the sexual lifestyle of long distance lorry drivers in India.

\section{Subjects, methods, and results}

A total of 5709 consecutive long distance lorry drivers who consented to take part in the questionnaire survey while passing through a check post on National High- way 5 at the Andhra-Orissa border were interviewed by three trained investigators over 105 days between March 1994 and August 1994. Interviews took 15-20 minutes.

The table shows that $87 \%$ of subjects (4949 men) were sexually promiscuous, of whom only $11 \%$ (563) used condoms during commercial sex. The percentage using condoms decreased with increasing age. In the 21-30 age group $(n=1766), 78 \%$ of unmarried sexually promiscuous men $(331 / 425)$ reported having 31-60 sexual partners during the past 12 months.

Only 29 of the 40 married men aged under 21 reported having sex daily. Almost half of subjects (2714; 47\%) drank alcohol daily early in the morning and got tremors if they didn't drink; the proportion increased with age, from $34 \%$ in men under 21 to $59 \%$

Sexual behaviour of 5709 long distance lorry drivers in India. Values in body of table are numbers (percentages); values in headings are numbers of respondents to question

\begin{tabular}{|c|c|c|c|c|c|c|c|c|c|c|c|c|}
\hline \multirow[b]{3}{*}{ Age group } & \multirow{3}{*}{$\begin{array}{c}\text { Sexually } \\
\text { promiscuous } \\
(\mathrm{n}=4949)\end{array}$} & \multicolumn{4}{|c|}{$\begin{array}{l}\text { No of sexual partners during past } \\
12 \text { months }\end{array}$} & \multirow{3}{*}{$\begin{array}{c}\text { Regular } \\
\text { condom use in } \\
\text { past } 12 \text { months } \\
\text { during } \\
\text { commercial sex } \\
(n=563)\end{array}$} & \multirow{3}{*}{$\begin{array}{c}\text { AIDS } \\
\text { knowledge† } \\
(\mathrm{n}=3997)\end{array}$} & \multicolumn{3}{|c|}{ Sexual practice‡ } & \multirow{3}{*}{$\begin{array}{l}\text { Alcohol } \\
\text { misuse§ } \\
(\mathrm{n}=2714)\end{array}$} & \multirow{3}{*}{$\begin{array}{c}\text { Sexually } \\
\text { transmitted } \\
\text { diseaseף } \\
(\mathrm{n}=1748)\end{array}$} \\
\hline & & \multirow[b]{2}{*}{$\leqslant 30$} & \multirow[b]{2}{*}{$31-40$} & \multirow[b]{2}{*}{$41-50$} & \multirow[b]{2}{*}{$51-60$} & & & \multirow{2}{*}{$\begin{array}{c}\text { Vaginal sex } \\
\text { only } \\
(\mathrm{n}=4572)\end{array}$} & \multicolumn{2}{|c|}{ Vaginal sex plus: } & & \\
\hline & & & & & & & & & $\begin{array}{c}\text { Anal sex } \\
(n=162)\end{array}$ & $\begin{array}{l}\text { Oral sex } \\
(n=215)\end{array}$ & & \\
\hline \multicolumn{13}{|l|}{ <21 years: } \\
\hline Married $(n=61)$ & $40(66)$ & 19 & 10 & 5 & 6 & $31(78)$ & $39(64)$ & $36(90)$ & $2(5)$ & $2(5)$ & & $28(70)$ \\
\hline Unmarried $(n=166)$ & $111(67)$ & 54 & 15 & 22 & 20 & $4(4)$ & $124(75)$ & $107(96)$ & $2(2)$ & $2(2)$ & & $60(54)$ \\
\hline Total $(n=227)$ & $151(66)$ & 73 & 25 & 27 & 26 & $35(23)$ & $163(72)$ & & & & $76(34)$ & $88(58)$ \\
\hline \multicolumn{13}{|l|}{ 21-30 years: } \\
\hline Married $(n=1087)$ & $978(90)$ & 614 & 163 & 93 & 81 & $102(10)$ & 701 (64) & 967 (98) & $5(1)$ & $6(1)$ & & $360(37)$ \\
\hline Unmarried $(n=679)$ & $425(63)$ & 94 & 66 & 143 & 122 & $16(4)$ & $581(86)$ & $413(97)$ & $7(2)$ & $5(1)$ & & $260(61)$ \\
\hline Total $(n=1766)$ & $1403(79)$ & 735 & 229 & 236 & 203 & $118(8)$ & $1282(73)$ & & & & $656(37)$ & $620(44)$ \\
\hline \multicolumn{13}{|l|}{ 31-40 years: } \\
\hline Married $(\mathrm{n}=2408)$ & 2207 (92) & 1417 & 590 & 189 & 11 & $216(10)$ & $1803(75)$ & 2060 (94) & $61(3)$ & $86(4)$ & & $704(32)$ \\
\hline Unmarried $(n=190)$ & $134(71)$ & 59 & 23 & 35 & 17 & $71(53)$ & $81(43)$ & $104(78)$ & $12(9)$ & $18(13)$ & & $52(39)$ \\
\hline Total $(n=2598)$ & $2341(90)$ & 1476 & 613 & 224 & 28 & $287(12)$ & $1884(72)$ & & & & $1320(51)$ & $756(32)$ \\
\hline Married $(n=1060)$ & $1012(95)^{\star *}$ & 528 & 284 & 140 & 60 & $101(10)$ & $641(60)^{* *}$ & $866(86)$ & $69(7)$ & 77 (8) & & $280(28)^{* \star}$ \\
\hline Unmarried $(n=58)$ & $42(72)^{\star *}$ & 18 & 9 & 15 & 0 & $22(52)$ & $27(47)^{\star *}$ & $19(45)$ & $4(10)$ & $19(45)$ & & $4(10)^{* \star}$ \\
\hline Total $(n=1118)$ & $1054(94)^{* *}$ & 546 & 293 & 155 & 60 & $123(11)$ & $668(60)^{* *}$ & & & & $662(59)^{\star}$ & $284(27)^{\star * *}$ \\
\hline
\end{tabular}

${ }^{*}$ Frequent and indiscriminate change of sexual partners, irrespective of marital status. †Correct answers to questions about the transmission and severity of AIDS.

fUsual practices during previous 12 months by men who had extramarital sex. §Drink daily early in the morning and get tremors if they don't drink.

१Genital ulcer, genital discharge, or both, during last 12 months, in men who had extramarital sex. ${ }^{*}{ }^{*} P<0.001, \chi^{2}$ test, compared with men aged $<21$ years. 